\title{
STUDI PENINGKATAN SIFAT TAHAN AIR KAIN KAPAS DENGAN MODIFIKASI TEKNIK COATING MENGGUNAKAN SUSPENSI ZnO DAN ASAM STEARAT
}

\author{
STUDY FOR IMPROVEMENT OF WATER REPELLENT PROPERTIES OF \\ COTTON FABRIC THROUGH THE COATING TECHNIQUE MODIFICATION \\ USING ZnO SUSPENSION AND STEARIC ACID
}

\author{
Agus Surya Mulyawan ${ }^{1}$, Jakariya Nugraha ${ }^{1}$, Rizky Berliana Wijayanti ${ }^{2}$, Arif Wibi Sana ${ }^{3}$, Doni \\ Sugiyana ${ }^{1}$
}

\author{
${ }^{1}$ Balai Besar Tekstil, Jl. Jend. A. Yani No. 390 Bandung \\ E-mail: texirdti@bdg.centrin.net.id \\ ${ }^{2}$ Balai Besar Keramik, Jl. Jend. A. Yani No. 392 Bandung \\ E-mail: rizkyberliana@gmail.com
}

\author{
${ }^{3}$ Politeknik Sekolah Tinggi Teknologi Tekstil, Jl. Jakarta No. 31 Bandung \\ E-mail: arifwibi_s@student.stttekstil.ac.id
}

Tanggal diterima: 31 Maret 2019, direvisi: 11 Juli 2019, disetujui terbit: 18 Juli 2019

\begin{abstract}
ABSTRAK
Salah satu proses penyempurnaan yang dapat dilakukan pada kain kapas adalah sifat tahan air menggunakan bahan kimia dan teknik tertentu sehingga permukaan kain menjadi kasar atau memiliki energi permukaan yang rendah. Seng oksida $(\mathrm{ZnO})$ dan asam stearat merupakan zat kimia yang dapat digunakan pada penyempurnaan tahan air dan diaplikasikan pada permukaan kain kapas dengan teknik penyemprotan dan perendaman. Penelitian ini bertujuan untuk mempelajari sintesis $\mathrm{ZnO}$ dari seng klorida dan natrium hidroksida serta kemampuannya bersama asam stearat dalam meningkatkan tahan air kain kapas dengan memodifikasi teknik coating yaitu kombinasi antara teknik penyemprotan dan perendaman. Struktur kristal ZnO hasil sintesis diamati menggunakan X-ray Diffraction (XRD), kain kapas setelah penyempurnaan tahan air diamati permukaannya menggunakan Scanning Electron Microscope (SEM), kapasitas daya serap air dievaluasi dengan menggunakan cara uji daya serap bahan tekstil, sedangkan sudut kontak air diukur dengan menggunakan metode sessile. Hasil penelitian menunjukan bahwa $\mathrm{ZnO}$ dan asam stearat yang diaplikasikan pada kain kapas dengan teknik penyemprotan-perendaman dapat meningkatkan ketahanan daya serap air lebih dari 3.600 detik dan sudut kontak air lebih dari $90^{\circ}$.
\end{abstract}

Kata kunci: tahan air, $\mathrm{ZnO}$, asam stearat, kain kapas, pelapisan

\begin{abstract}
One of finishing treatment that could be made on cotton fabric is water repellent property using certain chemicals and techniques so that the surface of the fabric becomes rough or has a low surface energy. Zinc oxide $(\mathrm{ZnO})$ and stearic acid are chemicals that could be used in refining water repellent and applied to the surface of cotton fabric with spraying and immersing techniques. The aim of this research is to study synthesis $\mathrm{ZnO}$ using $\mathrm{ZnCl}_{2}$ and $\mathrm{NaOH}$ also the ability of $\mathrm{ZnO}$ and stearic acid in improving water repellent cotton fabric using modify coating technique namely combination among spraying and immersing techniques. The crystalline structure of synthesis $\mathrm{ZnO}$ has been studied with X-Ray Diffraction (XRD), the surface cotton fabric as a result finishing process has been studied with a Scanning Electron Microscope (SEM), absorption capacity was evaluated using water drop test of textile substrat method, whileas water contact angle was measured using sessile method. The result showed that the $\mathrm{ZnO}$ and stearic acid which applied in cotton fabric with spraying and immersing technique could improve tenacity of water absorption up to 3600 second and water contact angle up to $90^{\circ}$.
\end{abstract}

Keywords: water repellent, $\mathrm{ZnO}$, stearic acid, cotton fabric, coating 


\section{PENDAHULUAN}

Proses penyempurnaan tekstil (finishing) adalah proses yang dilakukan pada bahan tekstil, baik secara mekanik maupun kimia setelah melalui satu atau beberapa proses persiapan (pretreatment). Finishing dilakukan untuk meningkatkan nilai estetik atau sifat dari bahan tekstil sehingga didapatkan fungsi tertentu pada produk akhir, misalnya kain tahan air, anti statik, anti bakteri, dan anti api. ${ }^{1,2,3,4,5}$

Finishing kain tahan air merupakan salah satu topik menarik bagi para peneliti selama beberapa dekade terakhir karena dapat diaplikasikan pada berbagai macam produk tekstil, misalnya untuk keperluan outdoor, militer, dan garmen yang terbuat dari kapas, poliester, sutra, atau campuran kapas-poliester. . $^{1,2,6,7,8,9,10,11}$

Kain dengan sifat tahan air dapat diperoleh dengan beberapa cara, yaitu memodifikasi permukaan hidrofilik kasar (rough) dengan lapisan hidrofobik dan atau melapisi permukaan kain (coating) dengan zat kimia yang memiliki energi permukaan rendah sehingga permukaannya dapat menahan air atau memiliki sudut kontak air lebih besar dari $90^{\circ}$ (hidrofob) atau $150^{\circ}$ (superhidrofob). ${ }^{12}$ Zat kimia yang efektif digunakan untuk meningkatkan sifat tahan air adalah fluorokimia atau zat kimia mengandung fluorin tetapi tidak efisien dan berpotensi negatif terhadap kesehatan manusia serta lingkungan. ${ }^{13}$ Sebagai alternatifnya maka digunakan zat kimia yang lain, misalnya parafin, garam logam, silikon, dan senyawa organo chrom. ${ }^{14}$ Liu et. al. (2010), melapisi kain kapas menggunakan tetraethoxysilane (TEOS) dengan teknik padding. ${ }^{6}$ Ekanayake et. al. (2018), melapisi kain poliester menggunakan nano $\mathrm{ZnO}$ kemudian asam stearat dengan teknik perendaman (layer-by-layer). ${ }^{7} \mathrm{Bi} \mathrm{Xu}$ dan Zaisheng Cai (2008), melapisi kain kapas dengan nano $\mathrm{ZnO}$ secara pad-dry-cure kemudian dilapisi kembali dengan nano $\mathrm{ZnO}$ secara hidrotermal. ${ }^{8}$ Nuraje et. al. (2013), membuat membran superhidrofob dengan teknik electrospinning. ${ }^{15}$ Novak et. al. (2017), memodifikasi permukaan kain poliester-kapas menjadi kasar menggunakan teknik plasma. ${ }^{16}$ Mohamed et. al. (2017), melapisi kain kapas, jute, dan linen dengan campuran parafin-asam stearat menggunakan teknik padding. ${ }^{17}$ Aslanidou et. al. (2018), mengaplikasikan nanosilika pada permukaan kain sutra menggunakan teknik spray. ${ }^{18}$

Berdasarkan penjelasan di atas maka penelitian tentang meningkatkan sifat tahan air kain kapas dengan $\mathrm{ZnO}$ dan asam stearat menggunakan kombinasi teknik spray dan perendaman belum pernah dilakukan. Tujuan dari penelitian ini adalah untuk mempelajari proses penyempurnaan tahan air menggunakan $\mathrm{ZnO}$ hasil sintesis dari $\mathrm{ZnCl}_{2}$ dan $\mathrm{NaOH}$, serta asam stearat.

\section{METODE \\ Bahan}

Bahan-bahan yang digunakan adalah kain kapas 100\% beranyaman polos 1/1, gramasinya 106 $\mathrm{g} / \mathrm{m}^{2}$, tetal lusinya (arah panjang kain) 2.913 helai per meter, tetal pakannya (arah lebar kain) 2.520 helai per meter, telah diproses penghilangan kanji (desizing) dan pemasakan (scouring). $\mathrm{NaOH}$ dan $\mathrm{ZnCl}_{2}$ grade pereaksi analitis didapat dari Merck, sedangkan asam stearat $\left\{\mathrm{CH}_{3}\left(\mathrm{CH}_{2}\right)_{16} \mathrm{CO}_{2} \mathrm{H}\right\}$, aseton, dan air demineralisasi dari Brataco.

\section{Peralatan}

Peralatan dalam penelitian ini digunakan dalam beberapa proses antara lain: sintesis dan karakterisasi $\mathrm{ZnO}$, coating kain kapas, dan evaluasi kain kapas setelah coating. Peralatan yang digunakan adalah: erlenmeyer $250 \mathrm{ml}$, magnetic stirrer, buret tetes, termometer, hot plate, sprayer, Curing HT-Steam Werner Mathis AG, Contact Angle Measurement (CAM) Kyowa 3.2, Scanning Electron Microscope (SEM) JEOL JSM-6510, dan X-ray Diffraction (XRD).

\section{Sintesis $\mathrm{ZnO}$}

Sintesis $\mathrm{ZnO}$ dilakukan berdasarkan metode penelitian yang dilakukan oleh Gusatti et. al (2010) dengan beberapa modifikasi. ${ }^{19}$ Bahan baku yang digunakan yaitu $\mathrm{ZnCl}_{2}$ dan $\mathrm{NaOH}$. Dibuat dua jenis larutan. Pertama (X), 6,8 gram $\mathrm{ZnCl}_{2}$ dilarutkan dalam $100 \mathrm{ml}$ air pada suhu kamar dan kedua (Y), 4 gram $\mathrm{NaOH}$ dalam $100 \mathrm{ml}$ air. Larutan $\mathrm{Y}$ dalam erlenmeyer dipanaskan hingga $50^{\circ} \mathrm{C}$, ke dalam larutan tersebut kemudian diteteskan larutan $\mathrm{X}$ selama 60 menit sambil diaduk. Pengadukan dilanjutkan hingga 120 menit setelah larutan X habis.

Material yang terbentuk dalam erlenmeyer disaring, dicuci beberapa kali dengan air demineralisasi, dikeringkan dalam oven pada suhu $70^{\circ} \mathrm{C}$ selama $14 \mathrm{jam}$, kemudian dalam tungku pada suhu $450^{\circ} \mathrm{C}$ selama 4 jam.

\section{Coating Kain Kapas}

Suspensi $\mathrm{ZnO}$ dibuat dengan cara mendispersikan 1,0 gram $\mathrm{ZnO}$ dalam $100 \mathrm{ml}$ air demineralisasi $(1,0 \%)$ kemudian diaduk menggunakan magnetik strirrer selama 30 menit. Suspensi $\mathrm{ZnO}$ disemprotkan (spraying) pada permukaan kain kapas berukuran $30 \mathrm{~cm}$ x $30 \mathrm{~cm}$ secara merata, dipanaskan pada suhu $100^{\circ} \mathrm{C}$ selama 3 menit, dilanjutkan perendaman (immersing) dalam larutan 0,05 $\mathrm{M}$ asam stearat selama 10 menit, kemudian dipanaskan kembali pada suhu $110^{\circ} \mathrm{C}$ selama 45 menit. ${ }^{13}$

Sebagai pembanding, perlakuan juga dilakukan pada kain kapas dengan spraying 1,0\% $\mathrm{ZnO}$ saja dan perendaman dengan asam stearat 0,05 
M saja. Kondisi selengkapnya disajikan pada Tabel 1 .

Tabel 1. Resep proses coating kain kapas

\begin{tabular}{c|c|c|c|c}
\hline Parameter & $\begin{array}{c}\text { Sampel } \\
\mathbf{1}\end{array}$ & $\begin{array}{c}\text { Sampel } \\
\mathbf{2}\end{array}$ & $\begin{array}{c}\text { Sampel } \\
\mathbf{3}\end{array}$ & $\begin{array}{c}\text { Sampel } \\
\mathbf{4}\end{array}$ \\
\hline $\begin{array}{c}\text { Asam } \\
\text { stearat (M) }\end{array}$ & - & - & 0,05 & 0,05 \\
\hline $\mathrm{ZnO}(\%)$ & - & 1,0 & - & 1,0 \\
\hline $\begin{array}{c}\text { Layer } \\
\text { spraying } \\
\mathrm{ZnO}\end{array}$ & - & $100^{\circ} \mathrm{C}$ & - & $100^{\circ} \mathrm{C}$ \\
\hline $\begin{array}{c}\text { Layer } \\
\text { immersing } \\
\text { asam stearat }\end{array}$ & - & - & $\begin{array}{c}110^{\circ} \mathrm{C} \\
45\end{array}$ & $\begin{array}{c}110^{\circ} \mathrm{C} \\
45 \\
\text { menit }\end{array}$ \\
\hline
\end{tabular}

\section{Pengujian dan Karakterisasi}

Pengamatan terhadap struktur kristal partikel $\mathrm{ZnO}$ dilakukan menggunakan $X$-ray Diffraction (XRD). ${ }^{19}$ Kain kapas hasil finishing diamati menggunakan SEM. ${ }^{7}$ Sudut kontak air diamati dengan metode sessile drop..$^{12}$ Sebanyak 8 $\mu \mathrm{l}$ air demineralisasi diteteskan pada permukaan kain kapas, setelah 10 detik diamati sudut kontaknya menggunakan CAM dan hasil ujinya merupakan rata-rata dari tiga kali pengukuran tiap sampelnya. Pengujian daya serap terhadap air menggunakan uji daya serap bahan tekstil. ${ }^{20}$ Kain diameter $15 \mathrm{~cm}$ dipasang pada lingkaran penyulam hingga permukaannya tegang. Setetes air diteteskan pada permukaan kain menggunakan buret. Dihitung waktu penyerapan airnya, yaitu pada saat air menetes kepermukaan kain hingga pantulan sinar pada tetesan air menghilang.

\section{HASIL DAN PEMBAHASAN \\ Karakterisasi ZnO}

Produk hasil sintesis ditunjukan pada

Gambar 1. Endapan putih terbentuk dari hasil reaksi hidrolisis dan polikondensasi antara $\mathrm{ZnCl}_{2}, \mathrm{NaOH}$, dan air. ${ }^{20}$ Mekanisme reaksi kimia yang menjelaskan tentang proses sintesis $\mathrm{ZnO}$ salah satunya dapat mengacu pada hasil penelitian Conde et. al. (2011) seperti ditunjukkan pada persamaan reaksi (1) sampai dengan (3). ${ }^{21}$

$$
\begin{aligned}
& \mathrm{ZnCl}_{2}+2 \mathrm{NaOH} \longrightarrow \mathrm{Zn}(\mathrm{OH})_{2}+2 \mathrm{NaCl} \\
& \mathrm{Zn}(\mathrm{OH})_{2}+\mathrm{H}_{2} \mathrm{O} \longrightarrow \mathrm{Zn}(\mathrm{OH})_{4}{ }^{2-}+2 \mathrm{H}^{+} \\
& \mathrm{Zn}(\mathrm{OH})_{4}{ }^{2-} \longrightarrow \mathrm{ZnO}+\mathrm{H}_{2} \mathrm{O}+2 \mathrm{OH}^{-}
\end{aligned}
$$

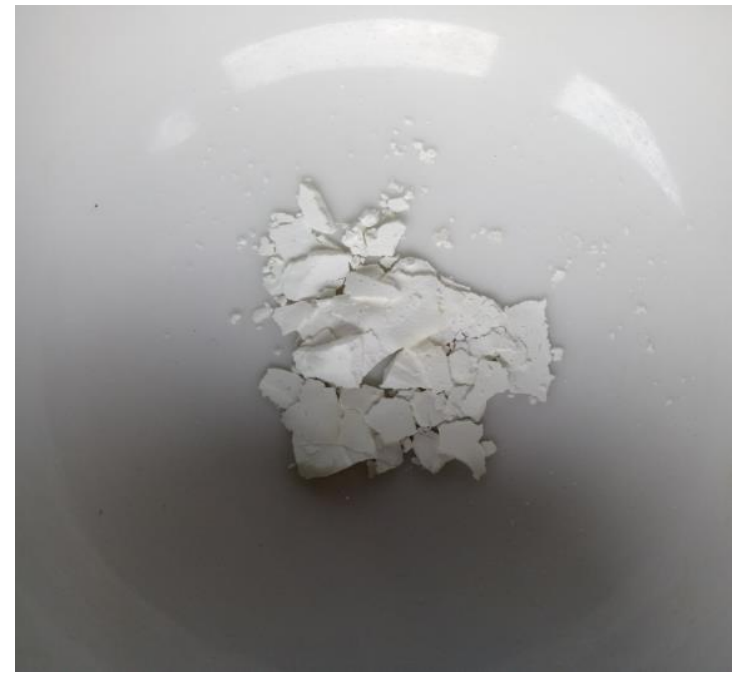

Gambar 1. Produk hasil sintesis setelah dari tungku.

$\mathrm{ZnO}$ terbentuk melalui proses dissolution dari $\mathrm{Zn}(\mathrm{OH})_{2}$ hasil penambahan $\mathrm{NaOH}$ yang merubah kondisinya menjadi alkali. Berikutnya $\mathrm{Zn}(\mathrm{OH})_{2}$ yang terbentuk dapat berubah menjadi $\mathrm{ZnO}$ pada rentang temperatur $30-100^{\circ} \mathrm{C} .{ }^{19,22}$

$\mathrm{ZnCl}_{2}$ dan $\mathrm{NaOH}$ yang dilarutkan dalam air demineralisasi menghasilkan larutan bening. Penambahan larutan $\mathrm{ZnCl}_{2}$ secara bertahap pada larutan $\mathrm{NaOH}$ dengan suhu $50^{\circ} \mathrm{C}$ dan adanya pengadukan, menjadikan warna larutan berubah menjadi putih kemudian terbentuk endapan putih. Kandungan air dihilangkan melalui penyaringan dan pengeringan sehingga yang tersisa adalah endapan putih $\mathrm{ZnO}$.

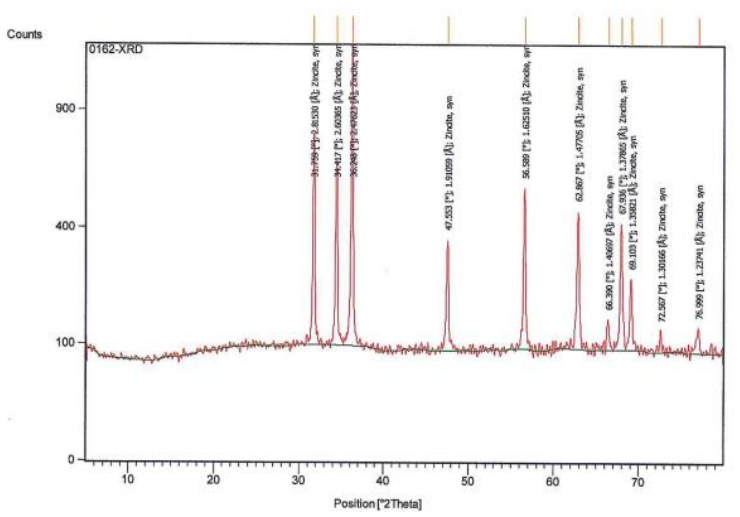

Gambar 2. Data pola difraksi sinar-X produk hasil sintesis.

Produk hasil sintesis diamati pula menggunakan XRD dan hasilnya ditunjukan pada Gambar 2. Puncak pengotor tidak ada sehingga produk hasil sintesis merupakan partikel dengan kemurnian tinggi. Semua puncak yang timbul merupakan pola difraksi sinar- $X$ yang mirip dengan hasil penelitian Gusatti et. al. (2010). Berdasarkan data referensi (ICSD 01-074-0534), pola tersebut menunjukkan terbentuknya senyawa oksida $\mathrm{ZnO}$ 
kristal heksagonal tipe wurtzite (space group $\left.\mathrm{P}_{3} \mathrm{mc}\right){ }^{19}$

\section{Coating Kain Kapas}

Pengamatan terhadap kain pada sampel 1 sampai dengan sampel 4 ditunjukkkan pada Gambar 3. ZnO dan asam stearat dapat diaplikasikan pada permukaan kain kapas menggunakan teknik spraying dan perendaman.

Perbedaan morfologi permukaan antara sampel 1 dan 3 menunjukan bahwa asam stearat dapat melapisi permukaan kain kapas, begitu pula dengan morfologi permukaan pada sampel 2 dan 4 . Tampak bahwa $\mathrm{ZnO}$ dapat diaplikasikan pada permukaan kain kapas menggunakan teknik spraying walaupun hasilnya belum mampu melapisi permukaan kain kapas secara merata.

\section{Daya Serap dan Sudut Kontak Air}

Hasil uji daya serap dan sudut kontak air disajikan pada tabel 2. Tahan air kain kapas meningkat $100 \%$ setelah dilakukan proses penyempurnaan, namun belum dapat dikategorikan
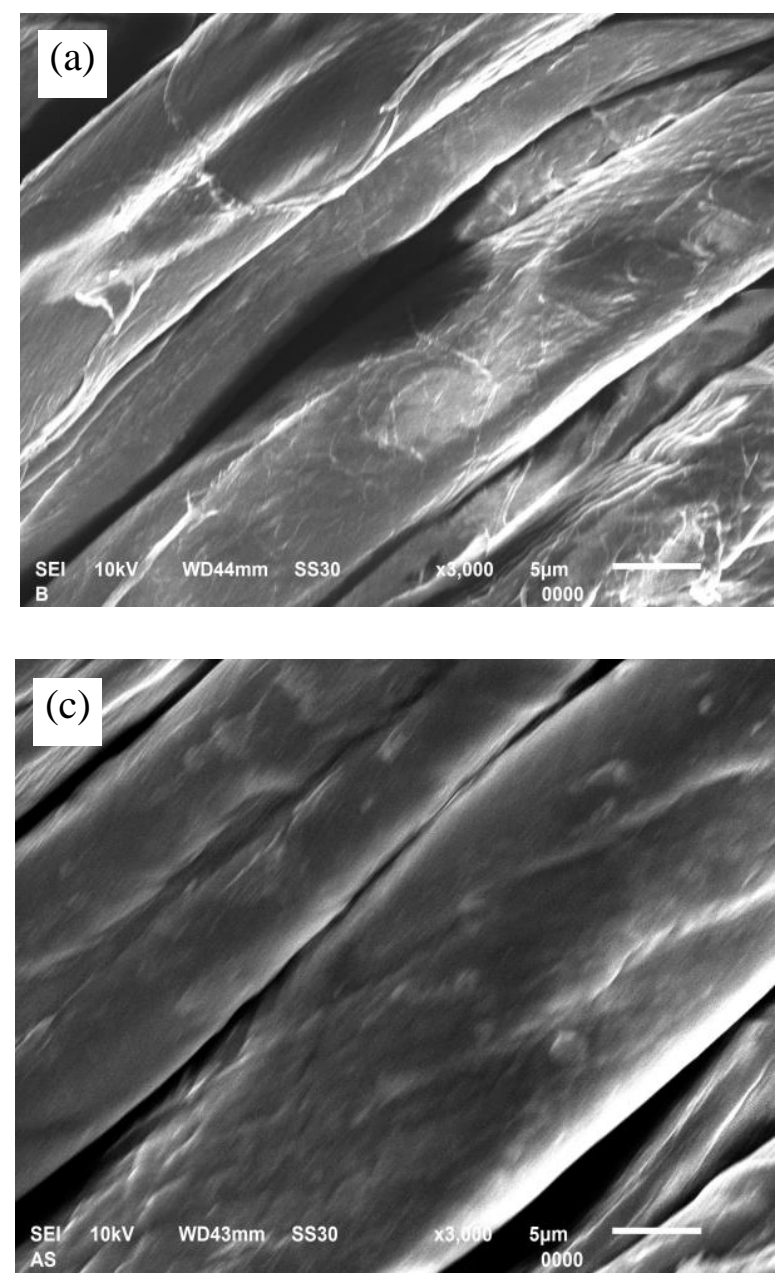

sebagai superhidrofob karena sudut kontak terhadap air masih kurang dari $150^{\circ}$.

Tabel 2. Hasil uji daya serap dan sudut kontak air pada permukaan kain kapas.

\begin{tabular}{c|c|c|c}
\hline Resep & $\begin{array}{c}\text { Daya } \\
\text { serap air } \\
\text { (detik) }\end{array}$ & \multicolumn{2}{|c}{ Sudut kontak air $\left(^{(\boldsymbol{})}\right.$} \\
\hline $\begin{array}{c}\text { Sampel } \\
1\end{array}$ & 0 & - & \\
\hline $\begin{array}{c}\text { Sampel } \\
2\end{array}$ & 25 & 41,4 & \\
\hline $\begin{array}{c}\text { Sampel } \\
3\end{array}$ & 1.650 & 96,38 & \\
\hline $\begin{array}{c}\text { Sampel } \\
4\end{array}$ & $>3.600$ & 119,06 & - \\
\hline
\end{tabular}
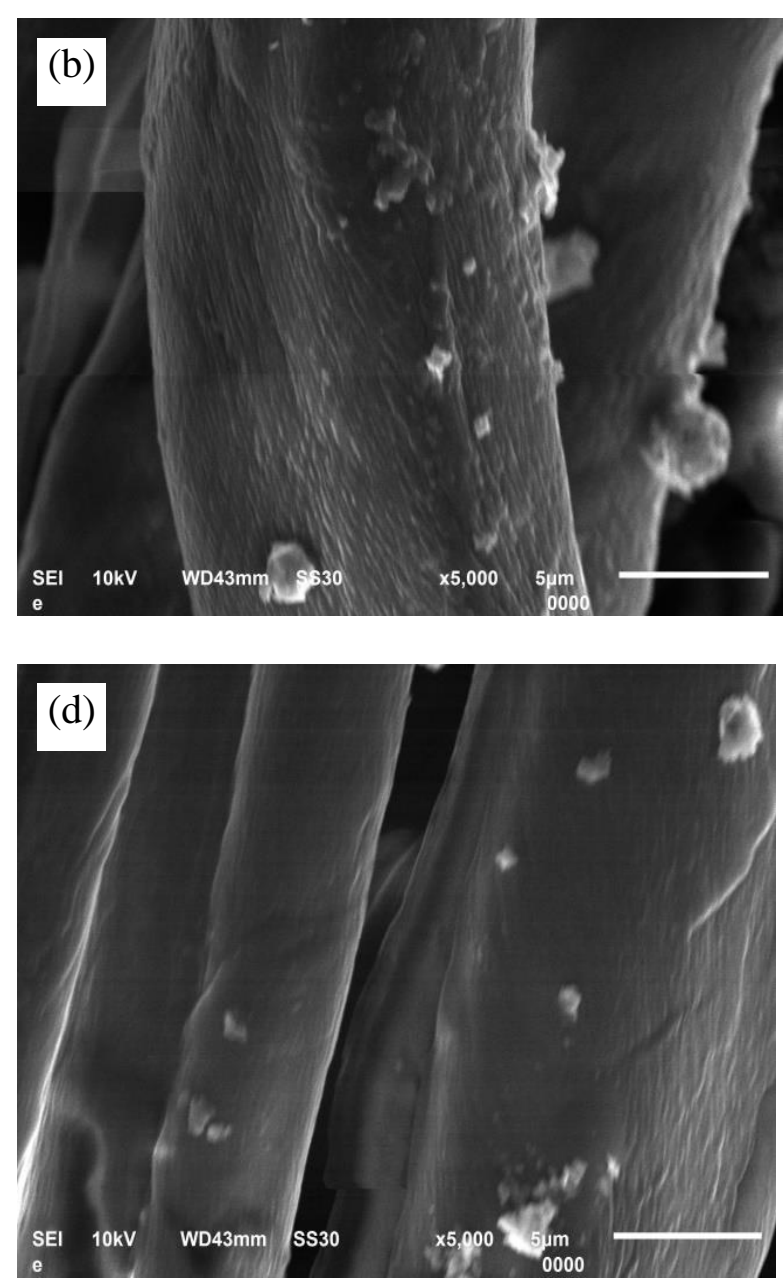

Gambar 3. Citra SEM: a) Sampel-1: kain kapas perbesaran 3.000x; b) Sampel-2: kain kapas dengan ZnO perbesaran 5.000x; c) Sampel-3: kain kapas dengan asam stearat perbesaran 3.000x; d) Sampel-4: kain kapas dengan $\mathrm{ZnO}$ dan asam stearat perbesaran 5.000x. 
Kain kapas tanpa penyempurnaan (Sampel 1) bersifat hidrofil karena memiliki struktur hidroksil yang melimpah sehingga air langsung menyebar dan terserap begitu diteteskan pada permukaannya, oleh karena itu pengamatan terhadap sudut kontak tidak dapat dilakukan. Setelah finishing, air yang diteteskan menjadi lebih spherical dan menghasilkan sudut kontak lebih besar dari $90^{\circ}$.

Sifat hidrofilik kain kapas setelah penyempurnaan dengan $\mathrm{ZnO}$ tidak berubah. Kondisi tersebut ditunjukan dengan hasil uji sudut kontak air yang masih di bawah $90^{\circ}$. Kain kapas dengan asam stearat sudut kontak airnya meningkat hingga $96^{\circ}$. Asam stearat merupakan salah satu material yang memiliki energi permukaan rendah dan jika direaksikan dengan gugus hidroksil pada kain kapas maka terjadi esterifikasi. Kondisi tersebut mengakibatkan tegangan permukaan kain kapas menjadi lebih kecil dari air sehingga kain kapas bersifat hidrofob. Beberapa penelitianpen menunjukan pula bahwa aplikasi asam stearat pada kain kapas secara perendaman dapat meningkatkan sudut kontak air di permukaan hingga di atas $90^{\circ} .10,13$

Kain kapas hasil penyempurnaan dengan $\mathrm{ZnO}$ dan asam stearat memiliki sudut kontak air paling tinggi. Aplikasi $\mathrm{ZnO}$ pada kain akan menghasilkan permukaan kain yang lebih kasar dan ketika dilapisi lagi dengan asam stearat maka energi permukaannya lebih kecil sehingga kemampuan dalam menahan air menjadi lebih tinggi.

Daya serap kain kapas terhadap air menurun setelah dilakukan finishing. Air yang diteteskan pada permukaan kain kapas akan bertahan diatasnya dan seiring waktu, volumenya akan berkurang karena terjadi evaporasi secara perlahan. Permukaan dengan energi yang lebih kecil dan kasar akan memiliki daya serap air lebih rendah. ${ }^{12}$ Hasil uji pada Tabel 2 menunjukan bahwa kain dengan $\mathrm{ZnO}$ dan asam stearat lebih tahan air dari kain lainnya. Perbedaan tersebut bisa terjadi karena adanya $\mathrm{ZnO}$ sehingga permukaan kain lebih mampu menahan air.

\section{KESIMPULAN}

Partikel $\mathrm{ZnO}$ dapat dibentuk dalam beberapa jam menggunakan bahan baku $\mathrm{ZnCl}_{2}$ dan $\mathrm{NaOH}$. Partikel $\mathrm{ZnO}$ yang disintesis memiliki tingkat kemurnian yang tinggi. Sifat kain kapas yang hidrofilik berubah menjadi hidrofobik setelah dilakukan penyempurnaan tahan air menggunakan suspensi $\mathrm{ZnO}$ dan asam stearat dengan teknik modifikasi pelapisan, yaitu spraying kemudian perendaman.

\section{PUSTAKA}

1. Roy Conway. Handbook of Technical Textiles. Elsevier Ltd. (2016).
2. Abo-Sosha et. al. Paravin Wax Emulsion as Water Repellent for Cotton/Polyester Blended Fabric. Journal of Industrial Textiles. 37(4), 315-325 (2008).

3. Hakeim et. al. Anti-Static and Functional Properties of Asminosilsesquioxane Oligomer Treated and Dye Fabrics. Journal of The Textile Association. 90-101. (2015).

4. Asma Farouk et. al. ZnO-Modified Hybrid Polymers as An Antibacterial Finish For Textiles. Textile Research Journal. 84(1), 4051 (2014).

5. Karim-Nejad et. al. Efficient Flame Retardant of Mercerized Cottton Through Cross-linking With Citric Acid and $\mathrm{ZnO}$ Nanoparticles Optimized by RSM Models, The Journal of The Textile Institute. 37-41 (2014).

6. Liu et. al. Preparation of Durable Superhydrophobic Surface by Sol-Gel Method With Water Glass and Citric Acid. J Sol Gel Sci Technology. 58, 18-23 (2011).

7. Ekanayake et. al. Fabrication of $\mathrm{ZnO}$ Nanoarchitectured Fluorin-Free Robust Superhydrophobic and UV Shielding Polyester Fabrics for Umbrella Canopies. RSC Advances. 8, 31406-31413 (2018).

8. $\mathrm{Bi} \mathrm{Xu}$ dan Zaisheng Cai. Fabrication of a Superhydrophobic ZnO Nanorod Array Film on Cotton Fabrics Via Wet Chemical Route and Hydrofobic Modification. Aplied Surface Science. 254, 5899-5904 (2008).

9. Abbas et. al. Fabrication of Durable and Cost Effective Superhydrophobic Cotton Textiles Via Simple One Step Process. Springer. (2014).

10. Kyuchul Lee et. al. Fabrication of Superhydrophobic Surface on a Cellulose-Base Material Via Chemical Modification. Bull.Korean Chem. 35(5), 1545-1548 (2014).

11. Dimitra Aslanidou dan Ioannis Karapanagiotis. Superhydrophobic, Superoleophobic and Antimicrobial Coatings For The Protection of Silk Textiles. Coatings. 8, 100-113 (2018).

12. Mojiri dan Aliofkhazrael. Effect of Surface Roughness on Wetting Properties. Elsevier. (2017).

13. Richard et. al. A Simple Cost Effective And Eco-Friendly Wet Chemical Process for The Fabrication of Superhydrophobic Cotton Fabrics. Applied Surface Science. 277, 302309 (2013).

14. Chinta et. al. Water Repellency of Textiles Through Nanotechnology. International 
Journal of Advanced Research in IT and Engineering. 2(1), 36-57 (2013).

15. Anitha et. al. Optical, Bactericidal and Water Repellent Properties of Electrospun NanoComposite Membranes of Cellulose Acetate and $\mathrm{ZnO}$. Carbohydrate Polymers 87, 1065 1072 (2012).

16. Novak et. al. Superhydrophobbic Cotton/Polyester Fabrics Modified by Barrier Discharge Plasma And Organosilanes. Polymer-Plastics Technology And Engineering. 1525-6111 (2017).

17. Mohamed et. al. Properties of Cellulosic Fabrics Treated by Water-Repellent Emulsions. Indian Journal of Fiber \& TextileResearch. 42, 223-229 (2017).

18. Dimitra Aslanidou dan Ioannis Karapanagiotis. Superhydrophobic, Superoleophobic and Antimicrobial Coatings for The Protection of Silk Textiles. Coatings. 8, 1-13 (2018).
19. Gusatti et. al. Production and Characterization of ZnO Nanocrystals Obtained by solochemical Processing at Different Temperatures. Journal of Nanoscience And Nanotechnology. 10, 4348-4351 (2010).

20. Asma Farouk. Using Nanotechnology in The Finishing of Cellulosic Fabrics. Dissertation of Chemistry Department. University of Duisburg-Essen. (2011).

21. Conde et. al. Preparation of $\mathrm{ZnO}$ Nanoparticles Without Any Annealing and Ripening Treatment. Journal of Materials Sciences and Engineering. 1, 985-990 (2011).

22. Frederic Demoisson et. al. Hydrothermal Synthesis of $\mathrm{ZnO}$ Crystals from $\mathrm{Zn}(\mathrm{OH})_{2}$ Metastable Phases at Room to Supercritical Conditions. Crystal Growth \& Design. 14, 5388-5396 (2014). 